\title{
Export Performance of Bangladesh: A Study on Selected Products
}

\author{
Mouri Mehtaj $^{1 *}$, Mohammed Junayed ${ }^{2}$ \\ ${ }^{1}$ Lecturer, Department of International Business, University of Dhaka, BANGLADESH \\ ${ }^{2}$ School of Business and Economics, United International University, Dhaka, BANGLADESH \\ *E-mail for correspondence: mourimehtaj@ymail.com
}

https://doi.org/10.18034/abr.v7i2.10

\begin{abstract}
Export is one of the major components of global business which secures a country's economic condition to a large extent. Developed as well as developing countries always try to increase their exports for the growth and expansion of their economies. This study indicates the trends of exporting from the early stage of our economic development. For that purpose, tea, raw jute and jute products, fisheries and leather have been chosen to figure out the situation. All the information has been collected from the secondary sources. The findings would be helpful for the government to take necessary strategies and policies for improving the situation.
\end{abstract}

Key words: Export, performance, economy, development

\section{INTRODUCTION}

Export is a task of international business in which goods are used by the citizens of other nation. In a broader sense, export is a function that includes goods, commodities and services produced in one country but sent to another country for future trading purpose. Government of every country takes favourable strategies and policies to increase their export. The reasons are: raising competitive advantage, standard of living, foreign exchange reserve and so on.

Developed countries always focus on their trends of export for both products and services. U.S., U.K., Japan, Hong Kong, Australia and other highly developed countries continuously increase their trade through export. Not only have the developed countries, developing nations also realized the importance of export. Thus, they are trying to create a network through bilateral and multi-lateral agreements. They believe these agreements would help them to improve their overall export situation. If export increases, then developing countries would compete with the developed nations in the arena of free trade.

Bangladesh, a developing country, is one of the rising economies in the world. Although, the country is facing a number of challenges, barriers and troubles, but still it is flourishing in different sectors. Bangladesh is quite competitive in RMG, jute, leather, human resource and other areas. Every year, huge amount of revenues are generating by selling these products around the world. It is not very easy to become competitive in the era of globalization as a developing nation, but Bangladesh is trying to reduce all types of local and international barriers that hamper export process.

\section{LITERATURE REVIEW}

Between 1990 to 2010, import reduces for "inward policy of trade liberalization" (Mazumder and Rana, 2016). On the other hand, export improves for the forward policy. Liberalization policy increases GDP, FDI, remittances and so on (Mazumder and Rana, 2016). Export sector of Bangladesh is performing well since 1990s, although there are some structural limitations (Rahman, 2017). The growth rate of export of Bangladesh was more than that of the SAARC countries (Rahman, 2017). Export performance of primary commodities is comparatively poor than that of manufactured commodities (Rahman, 2017).

Bangladesh is a country where its export performance has been found to be related with larger commodity diversification of exports (Roy, 1991). The country has a tendency to maintain its huge portion of world exports when the international demand shifts towards 
commodity composition (Roy, 1991). In the market distribution effects, agricultural goods have expressed comparatively better performance in exporting than that of manufactured products (Roy, 1991). Bangladesh is increasing its export as our entrepreneurs are maintaining strong network with the foreign countries (Faroque et al., 2016).

Between 1995 and 2012, Bangladesh increased it's export world market share by performing successfully in garments sector (Kathuria et al., 2016). In 2009, recession could not damage the economy of Bangladesh as the country is in a competitive situation (Taslim and Haque, 2011). Earlier, RMG products were our major exporting items (Textile Today, 2017). But now, knitwear, wovenwear, frozen foods, leather and leather goods, engineering products are dominating the world market share (Textile Today, 2017).

Thus, a number of studies have been found on export performance of Bangladesh. Unfortunately, all the studies have mentioned our export journey in a narrow way. Mostly, they focused on specific time period or product which didn't give a clear picture of this area. So, this study attempted to describe the export scenario of some selected products from 1972 to 2016 to illustrate an unambiguous impression.

\section{RESEARCH Questions}

- 1 . What are our major export items?

- 2. How is the journey of our fundamental export items?

\section{ObJectives Of the Study}

The broad objective of the study is to explore the trends in exporting some selective products. Apart from this broad objective, there are some specific objectives such as:

- To analyse the export condition of some leading products of Bangladesh.

- To identify the past export situation of our fundamental products.

- To compare the past and present environment in exporting major products of Bangladesh.

\section{Methodology}

The study was descriptive in nature. The data were collected from secondary sources such as websites, newspapers and research papers. This study also used published and unpublished documents from authentic sources. Four major products have been selected for conducting the study. They are: tea, raw jute and jute products, leather and fisheries. The reason behind choosing these products as these are traditionally exported since 1972-73. This study collected the trends of export of this selected products from 1972 to 2016 for realizing the overall situation and future potential.

\section{FINDINGS AND ANALYSIS ON EXPORT TRENDS}

Tea

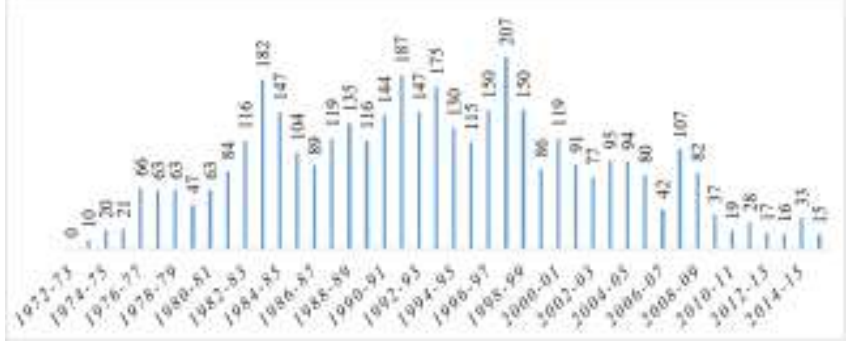

Figure 1: Export value of Tea from 1972-2016 (Taka in Crore)

Tea, an evergreen crop in Bangladesh; is basically agrobased and export-oriented. In 1972 Bangladesh government appointed a committee to investigate into the problems faced by the tea planters and provides useful suggestion such as raise productivity, reduce cost of production, and promote and strengthen the process of marketing to solve the problem of the tea planter. But later, in 80 s and 90 s the export of tea experienced an increasing growth as well.

In 2009 , the production rose by one percent but exports fell 68 percent. The trend goes same in 2012. The position of Bangladesh declines year by year mainly due to the fall of tea export with the increase of domestic consumption. Rapid urbanization, improved living standards, better distribution as a result of improved road communications, better marketing and promotional techniques and ensuring a high level of consistency and quality of the product are the reasons behind the scenario. Moreover, slow growth of production, inefficient garden workers as well as lower rate of production compared to other tea producing countries are other reasons that slowdown the export of tea from Bangladesh.

\section{Raw Jute \& Jute Products}

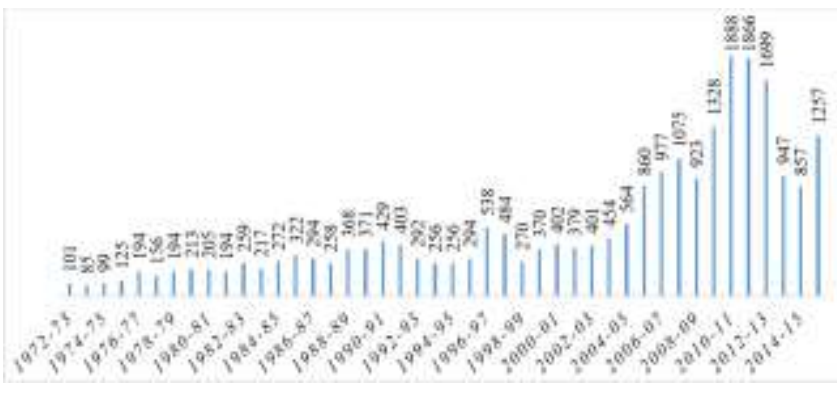

Figure 2: Export value of Raw Jute from 1972-2016 (Taka in Crore)

Global demand for raw and semi-processed jute was also high which had contributed to higher export revenue for Bangladesh until 1970s. However starting from '80s, due to lack of government policy and declining global demand, export earnings from Jute dried up significantly. The export of raw jute and jute product decreases with the blooming domestic demand by the institutional buyer to use jute products as a part of CSR initiatives of 'going green'. 


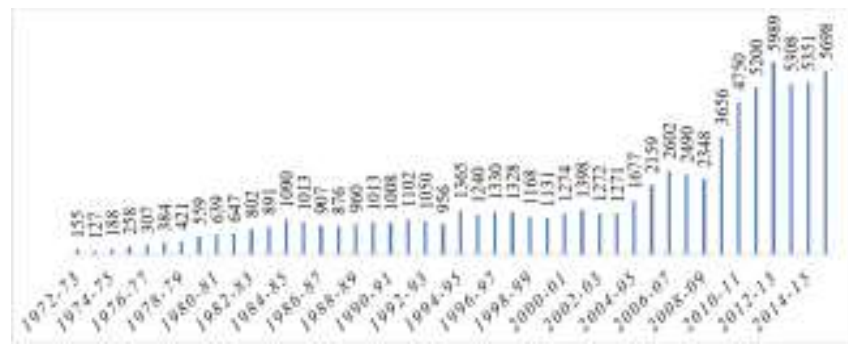

Figure 3: Export value of Jute Products from 1972-2016 (Taka in Crore)

The exporters had incurred significant financial losses due to frequent imposition of restriction on raw jute export by the government unilaterally in fiscal years (FY) 1984-85, 2009-10 and 2015-16. In 2015, Bangladesh imposed ban on export items of this industry to meet additional domestic demand and to follow mandatory jute packaging law.

But in 2017, the lift of anti-dumping law on Bangladeshi jute has showed an upward trend in exporting raw jute and jute products. So, the government needs to provide adequate support to develop this sector. Overall, jute products have overwhelming growth prospects and potential for higher value addition compared to export of raw jute.

\section{Leather}

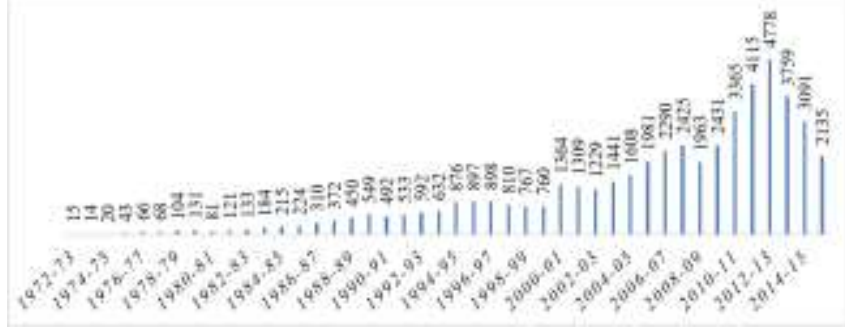

Figure 4: Export value of Leather from 1972-2016 (Taka in Crore)

After independence, Bangladesh government took over the responsibilities of managing all 30 tanneries. As a result, the sluggish activities of the factories occurred. For these circumstances, all those industries again returned to the private sector. Basically, large scale Leather factories has been developed in Bangladesh from 1970s. At the end of 1990, the leather industry got importance by foreign investment. But in recent years, growth of this sector has decreased because of lower earnings of some firms and due to higher competition among the firms. In 2017, the export of leather items decline due to the slow demand in international market; especially the slow consumption of U.S. market and the appreciation of taka against the dollar value. The manufacturer and exporter association said that the export growth is affected by decreasing unit price, appreciation of currency, shortage of gas and shutdown of factories due to labour unrest.

But the commerce minister said that the government has set $\$ 5$ billion export target of leather and leather goods by 2021. So, the government has decided to provide financial assistance for the export of leather and other products to attain the target of $\$ 60$ billion export by the golden jubilee of the country's independence.

\section{Fisheries}

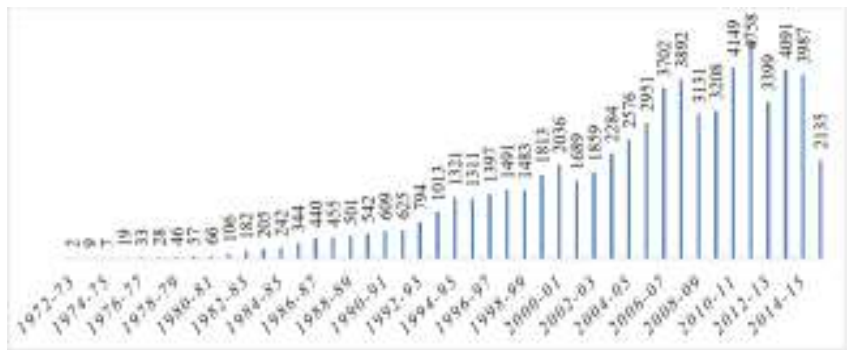

Figure 5: Export value of Fish from 1972-2016 (Taka in Crore)

Bangladesh was once a fish surplus country about half a century back when the population was less than 20 million. But with the rapid growth of population, fishing efforts increased greatly while culture and conservation were very insufficient to keep pace with population explosion.

From 1990s the growth of business increased rapidly. The main reasons for the growth of the industry were unplanned sanctioning of loan without any feasibility study, keeping the industry in the free-list for a long period of time, liberal financial support from the financial institutions, getting bank loans easily and quickly, increase amount of fish processing plant, better farming technology leading to enhanced production, demand for supply of animal protein is increasing to cater to the burgeoning population of Bangladesh and low cost and abundant resources for fish production and processing. The country's fish exports reached its peak in the fiscal year 2010-12. According to FAO, fish production under aqua-culture reached to 21 lakh metric tonns during the year 2015. This figure is almost double during the last 10 years of Bangladesh and occupying the 5 th position for the last 15 years in the aqua-fish production. Even then, the consumers are unhappy over the price of fishes they are to pay. So, there is still room to increase the fish production in Bangladesh.

\section{LIMITATIONS}

The study has focused very limited products to draw an inference. Inclusion of more value added products would have different results probably. Moreover, there was a time and budget constrain for conducting the study. These barriers failed to incorporate the opinions from trade analysts of Bangladesh.

\section{RESEARCH IMPLICATIONS}

This research has some mentionable implications such as:

- Government could take necessary actions to promote the export of potential items by taking further depth study in the area.

- From this research findings, respective authority could gather knowledge about our products and 
commodities playing role in export earnings. They can govern and ensure the export of these products without much trouble.

- By going through this research paper, government and related agencies would be able to find out the gaps and lacking in the present export market. Thus, they would cover these shortcomings by taking effective measures.

\section{REFERENCES}

Faroque, A. R., Ssussie, C. M. and Ferdous, A. S. (2016). Networking, business process innovativeness and export performance: the case study of South Asian low-tech industry. Journal of Business and Industrial Marketing, Vol. 32(6).

Kathuria S.; Malouche M; and Pierola MD. (2016). Strengthening Competitiveness In Bangladesh-Thematic Assessment: A Diagnostic Trade Integration Study, pp 1-37, Bangladesh's Trade Performance, https:/ / doi.org/10.1596/978-1-4648-0898-2_ch1

Majumder, S. C. and Rana, M.M. (2016). Trade Liberalization and it's Effect on the Economic Growth of Bangladesh: An Empirical Analysis. American Journal of Trade and Policy, Vol. 3(1), pp. 7-16.

Rahman, M. M. (2008). The Foreign Trade of Bangladesh: It's Composition, Performance, Trend and Policy, pp. 25-36. Available at: http://www.academia.edu/4259548/The_Foreign_Trade_of_ Bangladesh_Its_Composition_Performance_Trend_and_Policy

Roy, D. K. (1991). Determinants of Export Performance of Bangladesh. The Bangladesh Development Studies, Vol. XIX(4).

Roy, D. K. (1991). Determinants of Export Performance of Bangladesh:A Constant Market Share. The Bangladesh Development Studies, Vol. XIX(3).

Sanjay, K., Mariem, M., Martha, D. P. and Jose, Daniel, R. (2016). Strengthening Competitiveness in Bangladesh, Thematic Assessment: A Diagonstic Trade Integration Study, Bangladesh's Trade Performance, pp. 1-37. Available at: https://openknowledge.worldbank.org/handle/10986/22712

Taslim, M. A. and Haque, M. S. (2011). Export Performance of Bangladesh. International Growth Centre, pp. 1-47.

\section{Websites}

http:/ /archive.newagebd.net/182704/export-earnings-fromjute-yarn-twine-jump-after-raw-jute-export-ban/

http:/ /cpd.org.bd/we-need-to-achieve-about-13-exportgrowth-to-reach-50bn-export-target-by-2021-dr-moazzem/

http:/ /en.banglapedia.org/index.php?title=Tea_Industry http:/ / www.aplf.com/en-us/leather-fashion-news-andblog/news/30487/bangladesh-nbsp-value-of-finishedleather-exports-falls-by-one-third

http:/ / www.daily-sun.com/post/145378/Raw-jute-exportfalls-sharply-in-4-yrs

http:/ / www.dhakatribune.com/business/2016/09/01/process ed-leather-exports-keep-falling/

http://www.mediabangladesh.net/tea-gardens-bangladesh/

http:/ / www.thedailystar.net/business/export/govt-exportraw-jute-nepal-tofail-206797

http:/ / www.thedailystar.net/business/govt-bans-export-rawjute-182077

http:/ / www.thedailystar.net/business/jute-exports-indiamay-face-anti-dumping-duty-1300684

http:/ / www.thedailystar.net/fish-output-rises-5-times-in-30yrs-49279

http:/ / www.yarnsandfibers.com/news/news-tags/issuedban-raw-jute-exports

https:/ /bangladesheconomy.wordpress.com/2011/01/28/jutecontributes-4-68pc-in-export-earnings /

https://bdnews24.com/economy/2016/04/06/bangladeshexports-up-9-percent-in-first-three-quarters-of-fy-2015-16

https:// sourcingjournalonline.com/bangladesh-bans-all-rawjute-exports /

https:/ / tribune.com.pk/story/749294/millers-ask-govt-topromote-packaging-in-jute-bags /

https://www.businesshabit.com/2017/02/tea-manufacturingcompanies-in.html

$--0--$

Online Archive: https://abc.us.org/ojs/index.php/abr/issue/archive

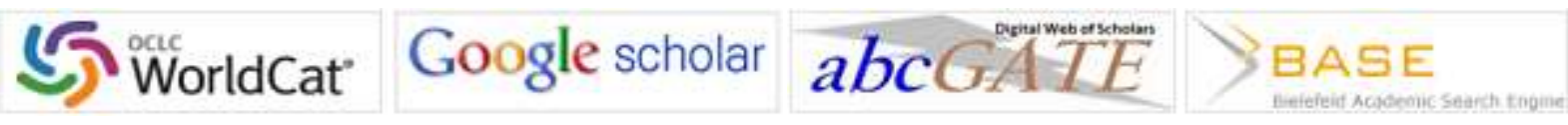

